\title{
Article \\ Carpachromene Ameliorates Insulin Resistance in HepG2 Cells via Modulating IR/IRS1/PI3k/Akt/GSK3/FoxO1 Pathway
}

\author{
Rania Alaaeldin ${ }^{1}$ (D) Iman A. M. Abdel-Rahman ${ }^{2}{ }^{(D}$, Heba Ali Hassan ${ }^{3}{ }^{(D}$, Nancy Youssef ${ }^{4}$, Ahmed E. Allam ${ }^{5}$, \\ Sayed F. Abdelwahab ${ }^{6}(\mathbb{D})$, Qing-Li Zhao ${ }^{7, *}$ and Moustafa Fathy ${ }^{8,9, *(D)}$
}

1 Department of Biochemistry, Faculty of Pharmacy, Deraya University, Minia 61111, Egypt; rania.alaadin@deraya.edu.eg

2 Department of Pharmacognosy, Faculty of Pharmacy, South Valley University, Qena 83523, Egypt; emanabdelraheem@svu.edu.eg

3 Department of Pharmacognosy, Faculty of Pharmacy, Sohag University, Sohag 82524, Egypt; heba.ali@pharm.sohag.edu.eg

4 Department of Clinical Pathology, Faculty of Medicine, Minia University, Minia 61512, Egypt; n.youssef@worc.ac.uk

5 Department of Pharmacognosy, Faculty of Pharmacy, Al-Azhar University, Assiut 71524, Egypt; ahmedallam@azhar.edu.eg

6 Department of Pharmaceutics and Industrial Pharmacy, College of Pharmacy, Taif University, Taif 21944, Saudi Arabia; sayed.awahab@mu.edu.eg

Citation: Alaaeldin, R.; Abdel-Rahman, I.A.M.; Hassan, H.A.; Youssef, N.; Allam, A.E.; Abdelwahab, S.F.; Zhao, Q.-L.; Fathy, M. Carpachromene Ameliorates Insulin Resistance in HepG2 Cells via Modulating IR/IRS1/PI3k/Akt/ GSK3/FoxO1 Pathway. Molecules 2021, 26, 7629. https://doi.org/ $10.3390 /$ molecules26247629

Academic Editors: Ligen Lin and Lishe Gan

Received: 13 November 2021 Accepted: 14 December 2021 Published: 16 December 2021

Publisher's Note: MDPI stays neutral with regard to jurisdictional claims in published maps and institutional affiliations.

Copyright: (c) 2021 by the authors. Licensee MDPI, Basel, Switzerland. This article is an open access article distributed under the terms and conditions of the Creative Commons Attribution (CC BY) license (https:// creativecommons.org/licenses/by/ $4.0 /)$.
7 Department of Radiology, Graduate School of Medicine and Pharmaceutical Sciences, University of Toyama, Toyama 930-0194, Japan

8 Department of Biochemistry, Faculty of Pharmacy, Minia University, Minia 61519, Egypt

9 Department of Regenerative Medicine, Graduate School of Medicine and Pharmaceutical Sciences, University of Toyama, Toyama 930-0194, Japan

* Correspondence: zhao@med.u-toyama.ac.jp (Q.-L.Z.); mostafa_fathe@minia.edu.eg (M.F.); Tel.: +81-764347267 (Q.-L.Z.); +20-862369075 (M.F.)

Abstract: Insulin resistance contributes to several disorders including type 2 diabetes and cardiovascular diseases. Carpachromene is a natural active compound that inhibits $\alpha$-glucosidase enzyme. The aim of the present study is to investigate the potential activity of carpachromene on glucose consumption, metabolism and insulin signalling in a HepG2 cells insulin resistant model. A HepG2 insulin resistant cell model (HepG2/IRM) was established. Cell viability assay of HepG2/IRM cells was performed after carpachromene/metformin treatment. Glucose concentration and glycogen content were determined. Western blot analysis of insulin receptor, IRS1, IRS2, PI3k, Akt, GSK3, FoxO1 proteins after carpachromene treatment was performed. Phosphoenolpyruvate carboxykinase (PEPCK) and hexokinase (HK) enzymes activity was also estimated. Viability of HepG2/IRM cells was over $90 \%$ after carpachromene treatment at concentrations $6.3,10$, and $20 \mu \mathrm{g} / \mathrm{mL}$. Treatment of HepG2/IRM cells with carpachromene decreased glucose concentration in a concentration- and time-dependant manner. In addition, carpachromene increased glycogen content of HepG2/IRM cells. Moreover, carpachromene treatment of HepG2/IRM cells significantly increased the expression of phosphorylated/total ratios of IR, IRS1, PI3K, Akt, GSK3, and FoxO1 proteins. Furthermore, PEPCK enzyme activity was significantly decreased, and HK enzyme activity was significantly increased after carpachromene treatment. The present study examined, for the first time, the potential antidiabetic activity of carpachromene on a biochemical and molecular basis. It increased the expression ratio of insulin receptor and IRS1 which further phosphorylated/activated PI3K/Akt pathway and phosphorylated/inhibited GSK3 and FoxO1 proteins. Our findings revealed that carpachromene showed central molecular regulation of glucose metabolism and insulin signalling via IR/IRS1/ PI3K/Akt/GSK3/FoxO1 pathway.

Keywords: carpachromene; HepG2 cells; insulin resistance; insulin receptor; PI3K/Akt/GSK3/FoxO1 pathway 


\section{Introduction}

Insulin resistance is a condition that arises from the defect in insulin-mediated actions on glucose and lipid metabolism, which occurs mainly in liver, muscles, and adipose tissues. This contributes to numerous human diseases including type 2 diabetes mellitus and cardiovascular diseases $[1,2]$. The causes underlying insulin resistance are a combination of genetic and environmental factors (e.g., diet and exercise). Adipose tissues predominantly contribute to insulin resistance. The limitation of adipose tissue expansion in response to large food intake leads to a high level of circulating lipids, particularly free fatty acids (FFAs) [3]. Insulin exerts its physiological action through binding to and activation of the plasma membrane-bound insulin receptor on target cells. Once activated, it initiates a downstream signaling cascade to phosphorylate the tyrosine residues of the insulin receptor substrate (IRS) family for their activation. IRS-1 (IRS1) and -2 (IRS2) are implicated in most of the metabolic actions mediated via insulin receptors [4]. The activated IRS proteins can further phosphorylate and activate phosphoinositide-3-kinase (PI3K) which in turn results in protein kinase B (Akt) phosphorylation and activation $[5,6]$. Insulin receptor activation and the consecutive phosphorylation/activation of signaling proteins, primarily IRS1, IRS2, PI3K, and Akt, are largely implicated in insulin action and response at target tissues [1]. Defects in the insulin signaling cascade has been associated with severe forms of insulin resistance and type 2 diabetes [7]. Currently, metformin is considered the first line therapeutic treatment for hyperglycemia and diabetes [8].

Approximately $30 \%$ of patients taking metformin develop nausea and bloating with abdominal pain, and $5-10 \%$ of patients are unable to continue on the medication [9]. Thus, screening and finding natural active compounds that could ameliorate insulin resistance and glucose metabolism is necessary.

Carpachromene is a natural bioactive compound that was isolated from the ethyl acetate fraction of fresh leaves of Ficus benghalensis [10]. Carpachromene was previously reported to exhibit cytotoxicity against HepG2, PLC/PRF/5 and Raji cancer cell lines [11]. It also induced apoptosis in human ovarian cancer cells, SW 626, by decreasing mitochondrial smac and increasing cytosolic smac [12]. The antimycobacterial activity of carpachromene was investigated, but it showed no activity against Mycobacterium tuberculosis $\mathrm{H}_{37} \mathrm{R}_{\mathrm{V}}$ in vitro [13]. In addition, carpachromene was examined as an antibrowning agent, but it showed no tyrosinase inhibition activity [14].

Looking for new pharmacological activities for existing candidates became essential [15-22]. Herein, we investigated, for the first time, the potential activity of carpachromene, which was shown to inhibit $\alpha$-glucosidase enzyme activity [23], on glucose consumption, metabolism, and insulin signaling in a HepG2 cells insulin resistant model.

\section{Results}

\subsection{Insulin Resistant Model (IRM) Development}

To obtain the insulin resistant model of HepG2 cells (HepG2/IRM), we examined the effect of different concentrations of insulin $(0.005,0.05,0.5,5,50 \mu \mathrm{mol})$ on glucose concentration for different time intervals 12, 24, 36, 48, as shown in Table 1 and Figure 1. As shown in Figure 1, cells incubated with $0.005 \mu \mathrm{M}$ of insulin for $24 \mathrm{~h}$ showed the lowest cellular glucose consumption when compared to the control cells without insulin treatment. Therefore, treatment of HepG2 cells with $0.005 \mu \mathrm{M}$ of insulin for $24 \mathrm{~h}$ was finalized to conduct HepG2/IRM cells. 
Table 1. Effect of different concentrations of insulin on glucose consumption in HepG2 cells at different time intervals to conduct IRM.

\begin{tabular}{|c|c|c|c|c|}
\hline \multirow{2}{*}{$\begin{array}{l}\text { Insulin Conc. } \\
\qquad(\mu \mathrm{M})\end{array}$} & \multicolumn{4}{|c|}{ Glucose Consumption (mmol/L) } \\
\hline & $12 \mathrm{~h}$ & $24 \mathrm{~h}$ & $36 \mathrm{~h}$ & $48 \mathrm{~h}$ \\
\hline- & $3.577 \pm 0.199$ & $4.441 \pm 0.087$ & $5.477 \pm 0.045$ & $6.200 \pm 0.092$ \\
\hline 0.005 & $0.432 \pm 0.406^{* * *}$ & $0.229 \pm 0.077^{* * *}$ & $1.750 \pm 0.270 * * *$ & $1.932 \pm 0.412^{* * *}$ \\
\hline 0.05 & $1.378 \pm 0.477^{* * *}$ & $1.803 \pm 0.310 * * *$ & $1.750 \pm 0.026^{* * *}$ & $2.062 \pm 0.139 * * *$ \\
\hline 0.5 & $1.563 \pm 0.445^{* * *}$ & $2.248 \pm 0.502 * * *$ & $2.232 \pm 0.310^{* * *}$ & $2.636 \pm 0.284^{* * * *}$ \\
\hline 5 & $1.507 \pm 0.841^{* * *}$ & $2.933 \pm 0.434^{* *}$ & $4.345 \pm 1.462 *$ & $5.620 \pm 0.923$ \\
\hline 50 & $2.916 \pm 0.670$ & $4.175 \pm 0.430$ & $6.124 \pm 0.114$ & $6.158 \pm 0.094$ \\
\hline
\end{tabular}

Values represent mean \pm SD from three independent repeats. Significant difference was analyzed by two-way ANOVA test followed by post hoc Dunnett test, where ${ }^{*} p<0.5{ }^{* *} p<0.01,{ }^{* * *} p<0.001$, compared to control non-insulin-treated cells.

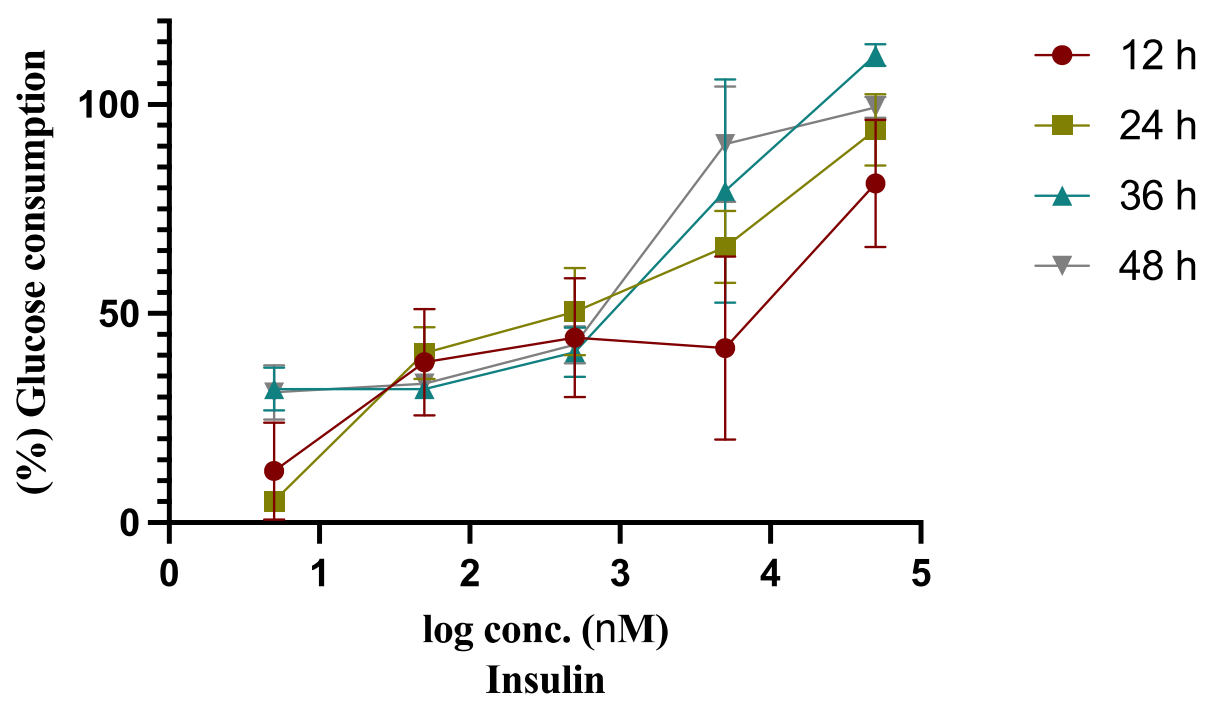

Figure 1. Establishment of insulin resistant model on HepG2 cells through examining the effect of different concentrations of insulin $(0.005,0.05,0.5,5,50 \mu \mathrm{M})$ on glucose consumption after 12, 24, 36, $48 \mathrm{~h}$, when compared to control non-insulin treated HepG2 cells. Bars represent mean \pm SD.

\subsection{Cell Viability Assay}

HepG2/IRM cells were treated with different concentrations of carpachromene or metformin $(0.4,1.6,6.3,10,20,25,100 \mu \mathrm{g} / \mathrm{mL})$ for $48 \mathrm{~h}$ to examine their cytotoxic activity on the cells. As shown in Figure 2, a significant $(p<0.01)$ decrease in cell viability started to occur from $6.3 \mu \mathrm{g} / \mathrm{mL}$ concentration of carpachromene or metformin on HepG2/IRM cells. However, according to Dewi et al., further examination can be preceded with compounds that show over $90 \%$ cell viability [24]. At the concentrations of $6.3,10,20 \mu \mathrm{g} / \mathrm{mL}$ carpachromene decreased $(p<0.01)$ cell viability to $95.46 \% \pm 2.57,94.18 \% \pm 1.91$, and $92.19 \% \pm 1.82$, respectively. At the concentrations of 25 and $100 \mu \mathrm{g} / \mathrm{mL}$, carpachromene significantly $(p<0.01$ and $p<0.001$, respectively) decreased cell viability to $85.43 \% \pm 4.01$ and $65.58 \% \pm 2.67$, respectively, when compared to untreated HepG2/IRM cells. 


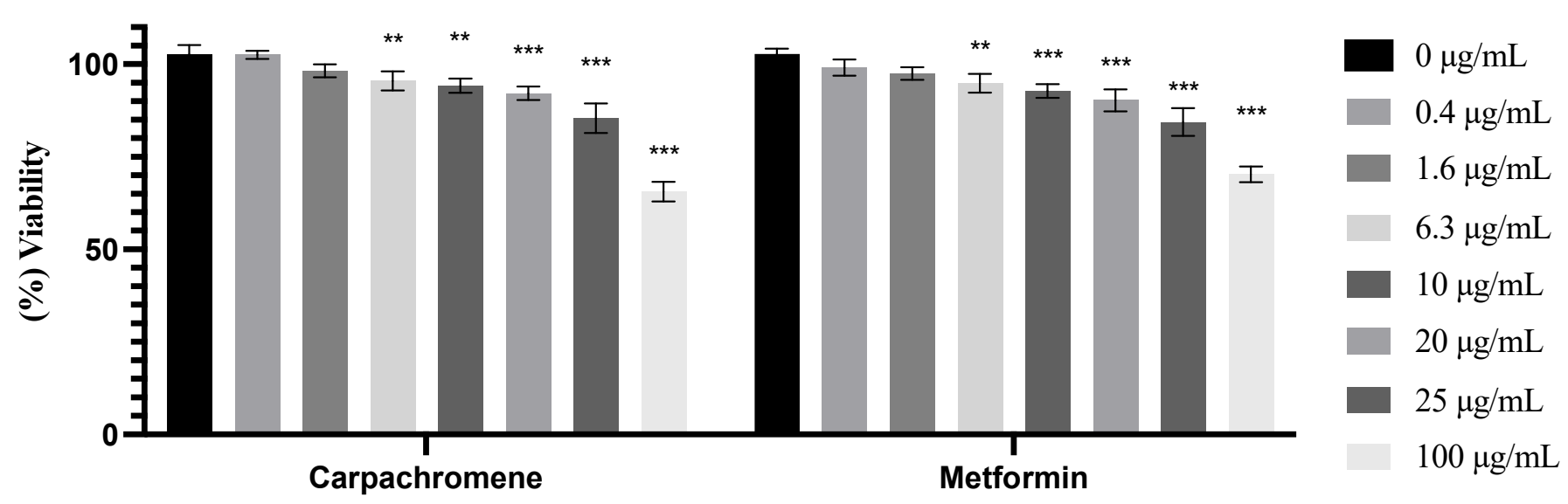

Figure 2. Cell viability after treatment with different concentrations $(0.4,1.6,6.3,10,20,25,100 \mu \mathrm{g} / \mathrm{mL})$ of carpachromene or metformin on HepG2/IRM cells for $48 \mathrm{~h}$. Bars represent mean $\pm \mathrm{SD}$. Significant difference was analyzed by two-way ANOVA test followed by post hoc Dunnett test, where ${ }^{* *} p<0.01$, ${ }^{* * *} p<0.001$, compared to untreated HepG2/IRM cells.

\subsection{Effect of Carpachromene on Glucose Concentration}

HepG2/IRM cells were treated with different concentrations of carpachromene $(5,10$, and $20 \mu \mathrm{g} / \mathrm{mL})$ for different time intervals $(12,24,36$ and $48 \mathrm{~h})$. Metformin was used as a positive control. Our findings revealed that carpachromene decreased glucose concentrations in the media in a concentration- and time-dependent manner (Figure 3). At the concentration of $5 \mu \mathrm{g} / \mathrm{mL}$, carpachromene significantly $(p<0.001)$ decreased glucose concentration to $6.4 \pm 0.53 \mathrm{mmol}, 3.45 \pm 0.32 \mathrm{mmol} / \mathrm{L}, 2.66 \pm 0.21 \mathrm{mmol} / \mathrm{L}$, and $2.04 \pm 0.18 \mathrm{mmol} / \mathrm{L}$ after 12 , 24,36 , and $48 \mathrm{~h}$ treatment, respectively, when compared to untreated HepG2/IRM cells. In addition, at the concentration of $10 \mu \mathrm{g} / \mathrm{mL}$, carpachromene significantly $(p<0.001)$ decreased glucose concentration to $5.94 \pm 0.42 \mathrm{mmol} / \mathrm{L}, 3.01 \pm 0.43 \mathrm{mmol} / \mathrm{L}, 2.12 \pm 0.25 \mathrm{mmol} / \mathrm{L}$, and $1.58 \pm 0.14 \mathrm{mmol} / \mathrm{L}$ after $12,24,36,48 \mathrm{~h}$ treatment, respectively, when compared to untreated HepG2/IRM cells. Furthermore, at the concentration of $20 \mu \mathrm{g} / \mathrm{mL}$, carpachromene significantly $(p<0.001)$ decreased glucose concentration to $4.47 \pm 0.41 \mathrm{mmol} / \mathrm{L}$, $2.84 \pm 0.33 \mathrm{mmol} / \mathrm{L}, 1.64 \pm 0.21 \mathrm{mmol} / \mathrm{L}$, and $1.07 \pm 0.18 \mathrm{mmol} / \mathrm{L}$ after $12,24,36$, and $48 \mathrm{~h}$ treatment, respectively, when compared to untreated HepG2/IRM cells.

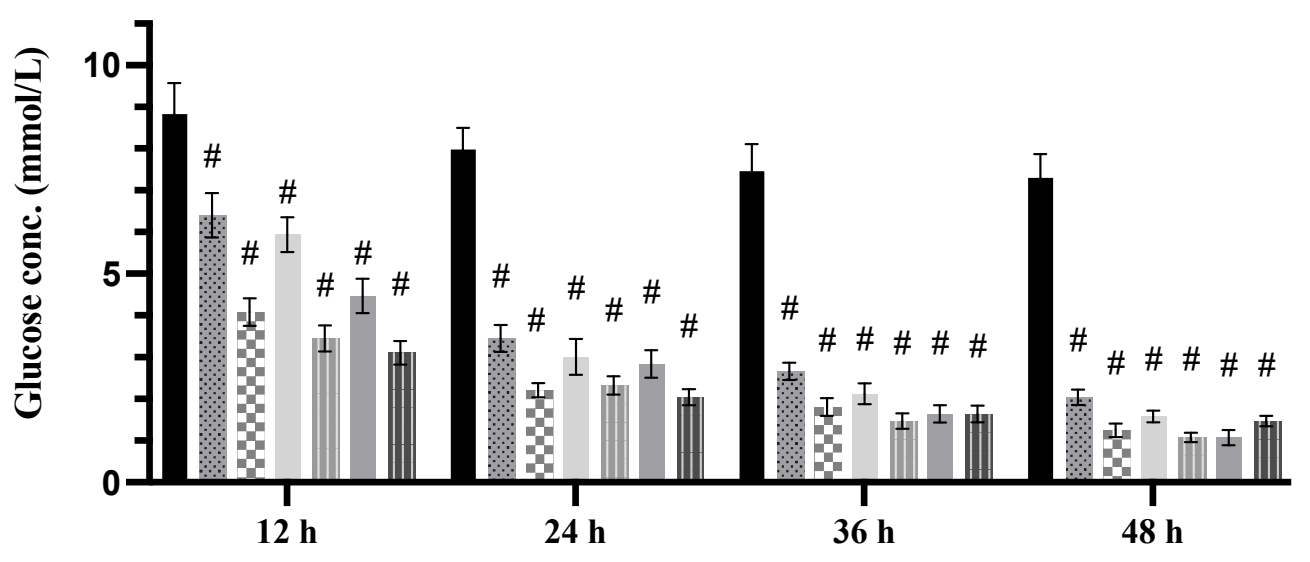

Untreated HepG2/IRM \% Carpachromene $5 \mu \mathrm{g} / \mathrm{mL}$ Hetformin $5 \mu \mathrm{g} / \mathrm{mL}$ Carpachromene $10 \mu \mathrm{g} / \mathrm{mL}$

||IIIII Metformin $10 \mu \mathrm{g} / \mathrm{mL}$ Carpachromene $20 \mu \mathrm{g} / \mathrm{mL}$ ||l||l| Metformin $20 \mu \mathrm{g} / \mathrm{mL}$

Figure 3. Glucose concentration in the media after treatment of HepG2/IRM cells with carpachromene or metformin at the concentrations of 5, 10, and $20 \mu \mathrm{g} / \mathrm{mL}$ for 12, 24, 36, and $48 \mathrm{~h}$. Bars represent mean $\pm \mathrm{SD}$. Significant difference was analyzed by two-way ANOVA test followed by post hoc Dunnett test, where \# $p<0.001$, compared to untreated HepG2/IRM cells. 


\subsection{Carpachromene Improved Cellular Glycogen Synthesis in HepG2/IRM Cells}

To investigate the effect of carpachromene on the glycogenesis pathway, we examined the intracellular glycogen content in control untreated HepG2/IRM cells and carpachromene-treated $(20 \mu \mathrm{g} / \mathrm{mL}) \mathrm{HepG} 2 / \mathrm{IRM}$ cells. Metformin was used as a positive control. As shown in Figure 4, the intracellular glycogen content was significantly $(p<0.01)$ increased to $157.43 \% \pm 10.03$, when compared to untreated HepG2/IRM cells.

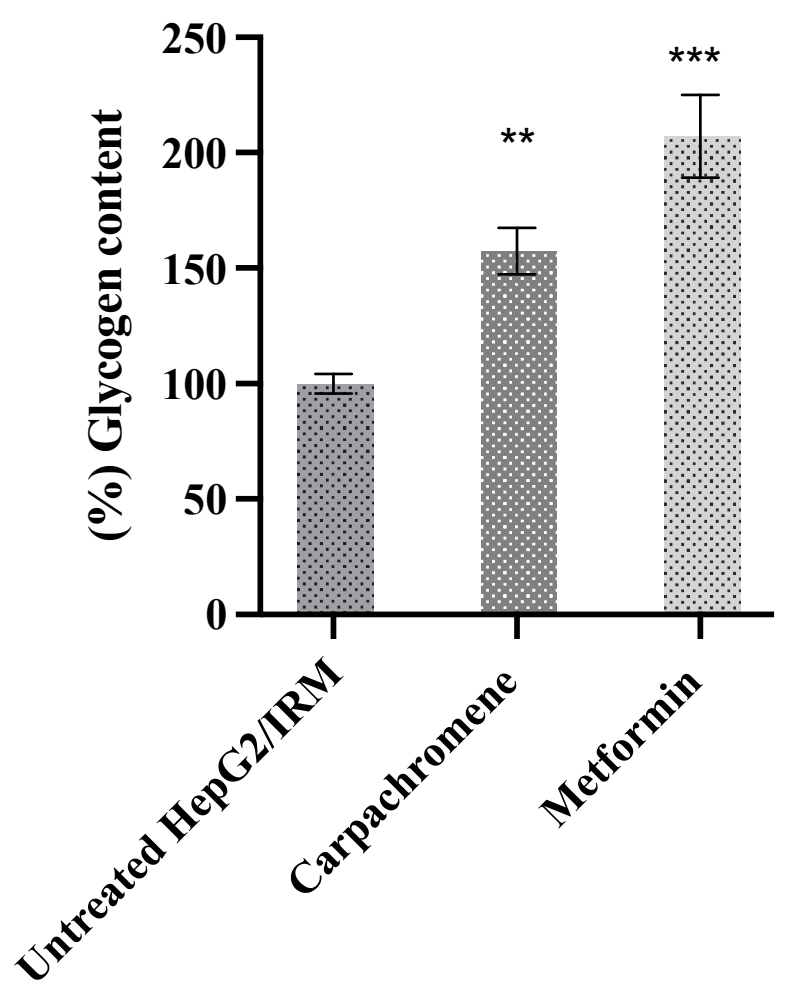

Figure 4. Glycogen content before and after treatment of HepG2/IRM cells with carpachromene or metformin $(20 \mu \mathrm{g} / \mathrm{mL})$, where untreated HepG2/IRM cells were considered $100 \%$. Bars represent mean \pm SD. Significant difference was analyzed by one-way ANOVA test followed by post hoc Dunnett test, where ${ }^{* *} p<0.01,{ }^{* * *} p<0.001$, compared to control untreated HepG2/IRM cells.

\subsection{Carpachromene Modulated the Expression of Proteins Involved in Insulin Signaling}

To understand the mechanism of action of carpachromene, we examined the phosphorylated and total protein expression of IR, IRS1, IRS2, PI3K, Akt, Glycogen synthase kinase (GSK3), and forehead box protein O1 (FoxO1) proteins. $\beta$-actin was used as an internal control. As shown in Figure 5, treatment of HepG2/IRM cells with $20 \mu \mathrm{g} / \mathrm{mL}$ carpachromene significantly $(p<0.01)$ increased the protein expression ratios of IR, IRS1, PI3K, Akt, GSK3, and FoxO1 when compared to untreated HepG2/IRM cells. On the other hand, there was no significant difference $(p>0.05)$ in IRS2 expression ratio before and after the treatment with carpachromene. 
A

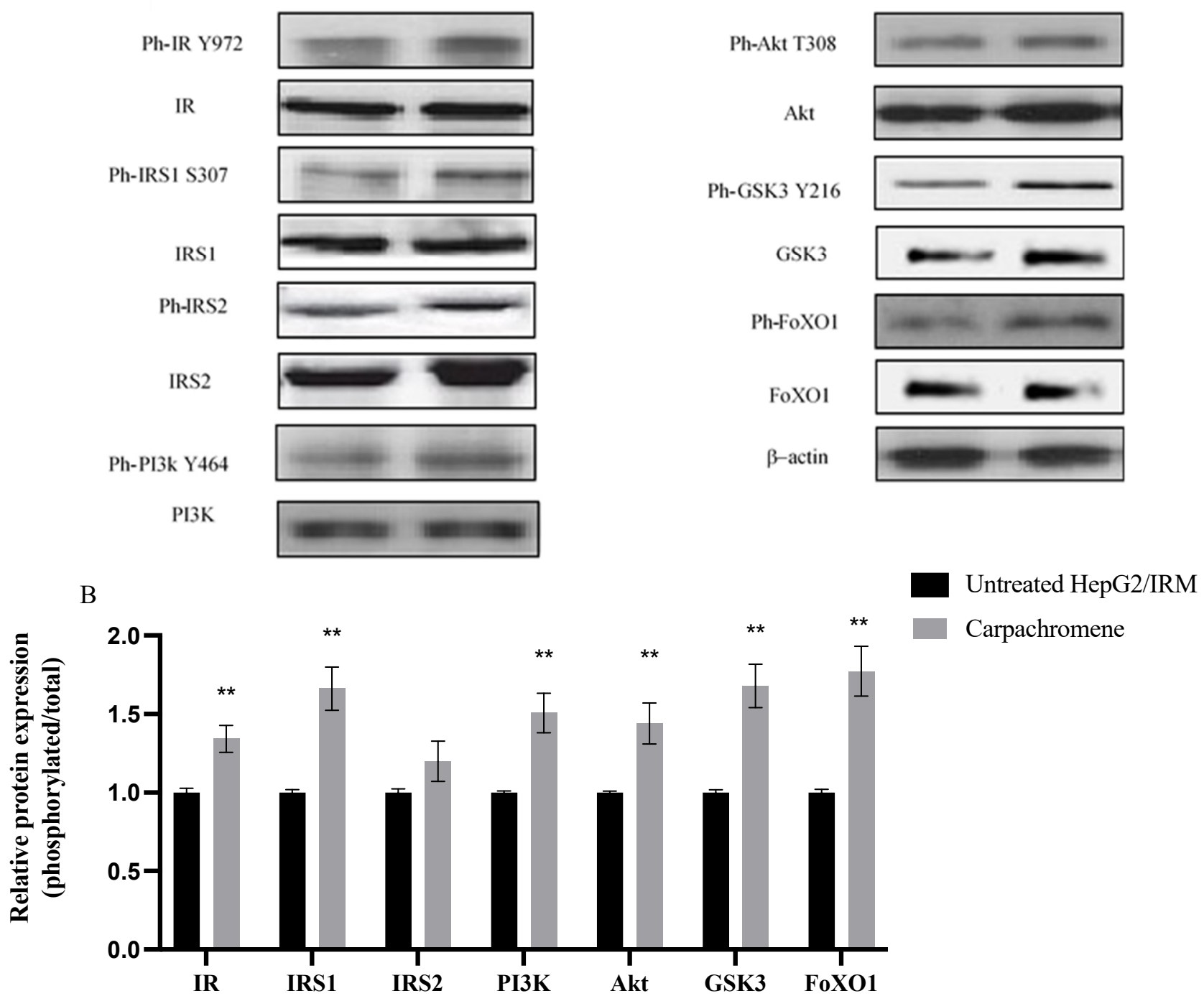

Figure 5. Effect of Carpachromene on the expression of phosphorylated and total proteins of IR, IRS1, IRS2, PI3K, Akt, GSK3, and FoxO1 proteins in HepG2/IRM cells. (A) Representative Western blots of phosphorylated and total proteins of IR, IRS1, IRS2, PI3K, Akt, GSK3, and FoxO1 in HepG2/IRM cells before (left lane) and after (right lane) treatment with $20 \mu \mathrm{g} / \mathrm{mL}$ carpachromene. $\beta$-actin was used as internal loading control. (B) Phosphorylated/total protein expression ratio in HepG2/IRM cells relative to untreated HepG2/IRM cells, after normalization to the corresponding $\beta$-actin protein expression. Bars represent mean $\pm \mathrm{SD}$. Significant difference was analyzed by student $\mathrm{t}$ test, where ${ }^{* *} p<0.01$, compared to untreated HepG2/IRM cells.

\subsection{Carpachromene Modulated Hepatic Enzymes Activity}

To examine the effect of carpachromene on the activity of hepatic metabolic enzymes, phosphoenolpyruvate carboxykinase (PEPCK) and Hexokinase (HK) hepatic enzyme activities were investigated. Metformin was used as a positive control. After treatment of $20 \mu \mathrm{g} / \mathrm{mL}$ carpachromene on HepG2/IRM cells, PEPCK enzyme activity was significantly $(p<0.001)$ decreased to $9.63 \mathrm{mU} / \mathrm{mg} \pm 0.743$ and the HK enzyme activity (represented as the amount of nicotinamide adenine dinucleotide (NADH) obtained from the reaction) was significantly $(p<0.001)$ increased to $89.6 \mathrm{nmol} \pm 7.66$, when compared to untreated HepG2/IRM cells, as shown in Figure 6. 

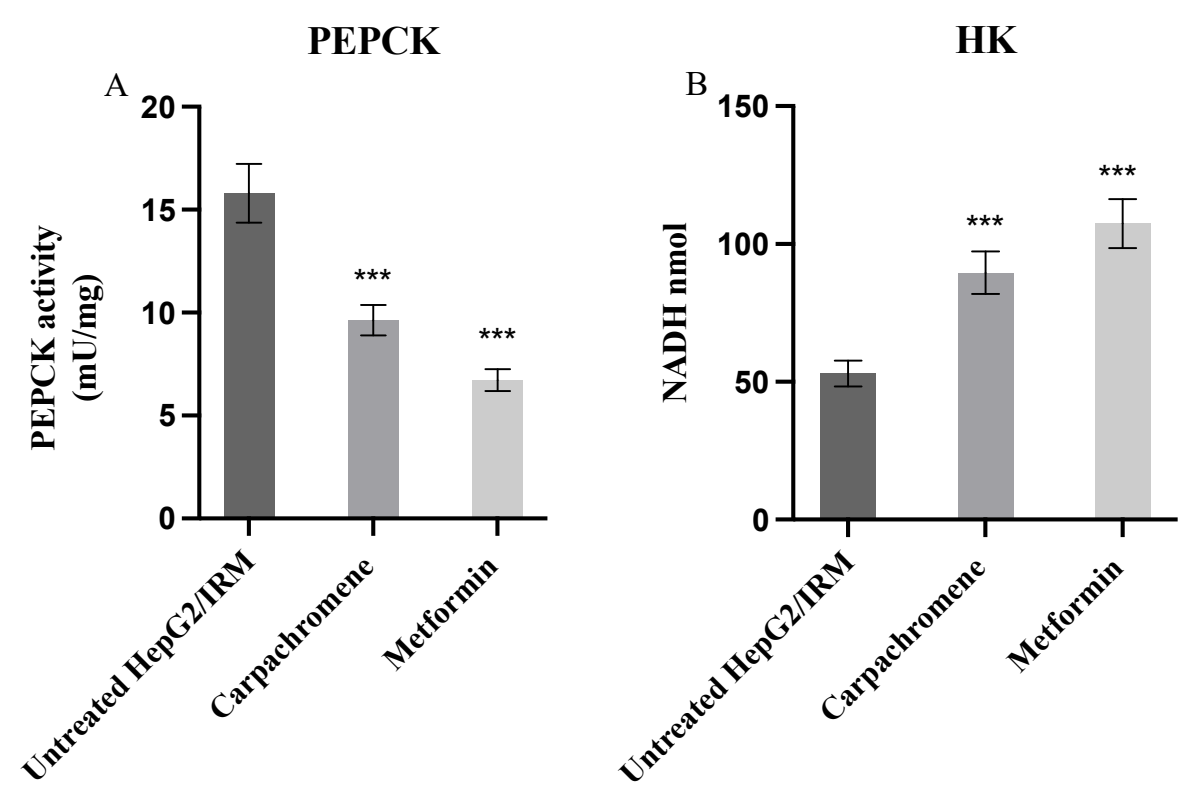

Figure 6. Effect of carpachromene $(20 \mu \mathrm{g} / \mathrm{mL})$ on the activity of (A) PEPCK and (B) HK enzymes on HepG2/IRM cells. Metformin was used as positive control. Bars represent mean $\pm \operatorname{SD}(n=3)$, significant difference was analyzed by one-way ANOVA followed by Dunnett test, ${ }^{* * *} p<0.001$, when compared to untreated HepG/IRM cells.

\section{Discussion}

Liver is a major insulin target organ which plays a predominant role in glucose and lipid metabolism. The direct insulin action on hepatocytes controls several metabolic pathways including glycolysis, glycogenesis, and gluconeogenesis [25]. The impairment of insulin action on its receptor results in a condition of insulin resistance which is associated by an increase in beta cell insulin production and hyperinsulinemia [26]. Hepatoma cell lines, particularly HepG2 cells, have been previously used to model hepatocytes in glucose metabolism and insulin signaling. Several studies induced an insulin resistant state in HepG2 cells to examine the antidiabetic activity of different compounds on hepatocytes $[8,27,28]$. Sefried et al. indicated that HepG2 cells were shown to have a gluconeogenic and hepaticgene expression pattern similar to that of the in vivo conditions [29]. The present study established an insulin resistant model on HepG2 cells as previously reported [30]. Different concentrations of insulin were examined at different time intervals to obtain the optimum time and concentration that showed the lowest glucose consumption. Our findings revealed that $0.005 \mu \mathrm{M}$ of insulin treatment for $24 \mathrm{~h}$ exerted the lowest glucose consumption, so we utilized it to obtain the insulin-resistant state of HepG2 cells for further analysis of carpachromene activity on insulin signalling and glucose metabolism.

Natural agents exhibited many in vitro [31,32] and in vivo [33,34] pharmacological actions in various disorders like carcinogenesis, [35] fibrosis, [36,37] angiogenesis, [38] and immunomodulation [39]. Several natural products have been examined for their hypoglycaemic activity against the insulin resistant model of HepG2 cells. According to Bian et al., natural triterpenoids isolated from Akebia trifoliata stem exerted inhibitory activity against $\alpha$-glucosidase enzyme. These compounds showed no cytotoxicity from 6.25-25 $\mu \mathrm{M}$ against HepG2/IRM, while toxic activity started to occur at higher doses [40]. A study by Yang et al. indicated that baicalein, a natural bioactive compound, showed cytotoxicity on HepG2 cells at concentration of $10^{-4} \mathrm{~mol} / \mathrm{L}$ [41]. Another study by Li et al. examined the activity of glycosides against HepG2 resistant cells where these compounds showed cytotoxity at 200 and $250 \mu \mathrm{M}$ [42].

Carpachromene is a natural flavonoid that can be found in various medicinal plants including Ficus nervosa, Calophyllum symingtonianum, Flindersia pimenteliana, Ficus formosana, and Ficus benglanesis $[10,11,13,23,43]$. Carpachromene was observed to have anti- 
plasmodial activity, a study by Robertson et al. indicated that carpachromene has shown anti-plasmodial principles against chloroquine-sensitive (3D7) and chloroquine-resistant (Dd2) Plasmodium falciparum with no cytotoxicity against HEK-293 cells at $40 \mu \mathrm{M}$ [11]. It exerted cytotoxic activity against HepG2, PLC/PRF/5 and Raji cancer cell lines that was indicated by XTT assay [11]. Furthermore, it modulated the expression of Smac protein resulting in induction of apoptosis for ovarian cancer cells [12].

To ensure the safety of carpachromene treatment on HepG2/IRM cells, cell viability assay was conducted. At the concentrations of $6.3,10,20 \mu \mathrm{g} / \mathrm{mL}$ of carpachromene treatment, cell viability assay showed more than $90 \%$ of viable HepG2/IRM cells. Hence, carpachromene was used at 5,10,20 $\mathrm{\mu g} / \mathrm{mL}$ for further analysis. Then, glucose concentration was estimated after carpachromene treatment at different time intervals. Our findings revealed a substantial decrease in glucose levels in the media indicating the increase of glucose uptake and consumption in a time- and concentration-dependant manner. In addition, the increase in glycogen synthesis was notably shown after carpachromene treatment in comparison to untreated HepG2/IRM cells. These results prompted the investigation of carpachromene activity on HepG2/IRM cells at the molecular level.

PI3K/Akt pathway plays a vital role in the metabolism inside the body. The Akt family was shown to regulate glycolysis, glycogenesis, and gluconeogenesis pathways in hepatocytes. Akt2, which is mainly expressed in insulin-responsive tissues, stimulates the expression of glucose transporter 4 (GLUT4) to increase glucose uptake by the cells. Akt promotes glycolysis and energy production via stimulation of HK enzyme to convert glucose to glucose-6-phosphate. In addition, Akt promotes glycogen production through the phosphorylation and inhibition of GSK3 which primarily inhibits glycogen synthase enzyme, a key enzyme in glycogen synthesis [44]. Another important protein in insulin signalling is FoxO1 protein, which is one of the main targets of Akt that was found to increase the expression of PEPCK and glucose-6-phosphatase enzymes. Akt primarily phosphorylates and inhibits FoxO1 proteins with further inhibition on gluconeogenesis pathway [45]. In the present study, carpachromene treatment of insulin resistant HepG2 cells increased the expression ratio of IR, IRS1, PI3K, Akt, GSK3, and FoxO1 proteins. We speculate that carpachromene increased the expression ratio of insulin receptor and IRS1 with further down-stream activation of PI3K/Akt pathway to stimulate glucose uptake and glycolysis.

Alternatively, the activation of the PI3K/Akt pathway led to the inhibition of the GSK3 enzyme with further increasing glycogen synthase activity and glycogenesis. In addition, the PI3K/Akt pathway inhibited the FoxO1 protein leading to the inhibition of PEPCK and glucose-6-phosphatase enzymes resulting in the inhibition of the gluconeogenesis pathway. Finally, carpachromene showed no significant activity on the expression ratio of IRS2.

In summary, carpachromene is a natural active compound that was previously shown to inhibit $\alpha$-glucosidase enzyme activity. It increased glucose consumption and uptake in a concentration- and time- dependant manner, and it also increased glycogen content in HepG2/IRM. On a molecular basis, carpachromene stimulated the phosphorylation of the insulin receptor and IRS1 proteins, which consequently activated the PI3K/Akt pathway. PI3K/Akt centrally regulates the metabolic pathway through the increase of glucose uptake via glucose transporter, GLUT4, and the increase of hexokinase enzyme activity to stimulate glycolysis. Furthermore, PI3K/Akt stimulates glycogenesis through the phosphorylation and inhibition of GSK3 enzyme. Additionally, PI3K//Akt inhibits gluconeogenesis through the phosphorylation and inhibition of FoxO1 protein. The present study proposed, for the first time, the antidiabetic activity of carpachromene via the IR/IRS1/PI3K/Akt/GSK3/FoxO1 pathway.

\section{Materials and Methods}

\subsection{Isolation of Carpachromene}

Carpachromene was isolated as previously described [10]. Briefly, it was extracted from the ethyl acetate fraction of fresh leaves of Ficus benghalensis and identified by ${ }^{1} \mathrm{H}-\mathrm{NMR}$ 
and ${ }^{13} \mathrm{C}$-NMR spectral data, shown in the Supplementary Data. The chemical structure of carpachromene is shown in Figure 7.<smiles>CC1(C)C=Cc2c(cc3oc(-c4ccc(O)cc4)cc(=O)c3c2O)O1</smiles>

Figure 7. Chemical structure of carpachromene extracted from the ethyl acetate fraction of fresh leaves of Ficus benghalensis.

\subsection{Cell Culture and Induction of Insulin Resistant HepG2 Cell Model}

HepG2 cells were obtained from American Type Culture Collection (ATCC, Manassas, VA, USA). Fresh Dulbecco's Modified Eagle's Medium (DMEM, Sigma-Aldrich, Inc, St. Louis, MO, USA) was used as a culture medium, augmented with 10\% foetal bovine serum (FBS, Biosolutions International, Melbourne, Australia), $100 \mathrm{U} / \mathrm{mL}$ Penicillin and $1 \%$ streptomycin (Invitrogen, Grand Island, NY, USA) in a humidified $5 \% \mathrm{CO}_{2}$ atmosphere at $37^{\circ} \mathrm{C}$.

Insulin resistant HepG2 cell model was accomplished as described [30]. In brief, cells were cultured in FBS-free medium for $6 \mathrm{~h}$, then treated with insulin (Sigma-Aldrich Inc., St. Louis, MO, USA) at concentrations of $0.005,0.05,0.5,5$, and $50 \mu \mathrm{M}$ for different time intervals of $12,24,36$, and $48 \mathrm{~h}$ in three independent repeats. Glucose concentration was assayed in $10 \mu \mathrm{L}$ of the media utilizing glucose assay kit (Signa-Aldrich Inc.) according to the manufacturer's instructions. The percentage of cellular glucose consumption was determined as the difference between glucose concentration before and after insulin treatment relative to control non-insulin treated cells.

The optimum incubation time and insulin concentration for conducting the insulin resistant model (IRM) were determined. The finalized insulin resistant HepG2 cells were called HepG2/IRM.

\subsection{Cell Viability Assay}

Cell viability assay was achieved using MTT reagent [3-(4, 5-dimethyl thiazol-2yl)-2, 5diphenyltetrazolium bromide] (Sigma Aldrich, Inc, St. Louis, MO, USA). After HepG2/IRM cells were obtained, 10,000 cells were seeded per well in triplicates in 96-well plates. Then, the cells were treated with different concentrations $(0.4,1.6,6.3,10,20,25$, and $100 \mu \mathrm{g} / \mathrm{mL})$ of carpachromene or metformin. After incubation for $48 \mathrm{~h}, 10 \mu \mathrm{L}$ of MTT $(5 \mu \mathrm{g} / \mathrm{mL})$ was added per well and incubated in the dark for $3 \mathrm{~h}$ at $37^{\circ} \mathrm{C}$. To dissolve the Formazan crystals that were formed, $100 \mu \mathrm{L}$ of DMSO were used and absorbance was measured using an ELISA reader (Multiskan ${ }^{\mathrm{TM}}$ FC microplate photometer, ThermoFisher Scientific, Life technologies Ltd., Paisley, UK) at $570 \mathrm{nM}$ as described [46].

\subsection{Carpachromene Effect on Glucose Concentration in HepG2/IRM}

HepG2/IRM cells were obtained, and 10,000 cells were seeded in 96 well-plates in triplicates. Then, cells were treated with non-toxic concentrations of carpachromene $(5,10,20) \mu \mathrm{g} / \mathrm{mL}$ for different durations. Metformin was used as a positive control. Glucose concentration was assayed in $10 \mu \mathrm{L}$ of the medium after 12, 24, 36, and $48 \mathrm{~h}$ of treatment using glucose assay kit (Sigma-Aldrich, Inc., St. Louis, MO, USA) according to the manufacturer's instructions [27]. 


\subsection{Determination of Intracellular Glycogen Content}

To examine the effect of carpachromene on intracellular glycogen, HepG2/IRM cells were seeded into a 6-well plate at a density of $3 \times 10^{5}$ cells/well. Cells were treated with $20 \mu \mathrm{g} / \mathrm{mL}$ carpachromene for $24 \mathrm{~h}$. Metformin was used as a positive control. Then, cells were washed three times with PBS. Glycogen assay kit (\#ab65620, Abcam, Cambridge, UK) was utilized according to the manufacturer's instructions. Microplate reader (ROBONIK P2000 ELISA Reader, OBONIK, Thane, India) was used to measure absorbance at 570 $\mathrm{nm}$. Additionally, the protein content of HepG2/IRM cells was quantified by Bradford method [47], and the values were showen as a ratio of glycogen $(\mathrm{mg}) /$ protein $(\mathrm{mg})$. Then, a percentage ratio was calculated where untreated HepG2/IRM cells were considered $100 \%$.

\subsection{Analysis of Protein Expression}

The present study investigated the protein expression levels of phosphorylated insulin receptor (ph-IR) (\#ab5678, Abcam), total insulin receptor (IR) (\#ab137747, Abcam), phosphorylated IRS1 (ph-IRS1; \#ab1194), total IRS1 (IRS1; ab40777), phosphorylated IRS2 (phIRS2; \#07-1517, Sigma Aldrich Inc.), total IRS2 (RS2) (\#ab245386, Abcam), phosphorylated PI3K (ph-PI3K) (\#ab138364, Abcam), total PI3K (\#ab154598), phosphorylated Akt (ph-Akt; \#ab38449, Abcam), total Akt (Akt) (\#ab188099, Abcam), phosphorylated GSK3 (ph-GSK3; \#ab75745, Abcam), total GSK3 (\#ab131356, Abcam), phosphorylated FoxO1 (ph-FoxO1; \#ab131339, Abcam), and total FoxO1 (FoxO1; \#ab39670, Abcam). Sodium dodecyl sulphatepolyacrylamide gel electrophoresis (SDS-PAGE) analysis was performed. HepG2/IRM cells were treated with $20 \mu \mathrm{g} / \mathrm{mL}$ of carpachromene for $24 \mathrm{~h}$. After washing with PBS, the protein extraction was performed in RIPA lysis buffer, containing $50 \mathrm{mM}$ Tris-Cl, $\mathrm{pH}$ 7.5; $0.1 \%$ SDS, $150 \mathrm{mM} \mathrm{NaCl}, 0.5 \%$ Sodium deoxycholate, $1 \mathrm{mM}$ PMSF, and $1 \%$ Nonidet P-40, supplemented with the complete protease inhibitor cocktail (Roche, Mannheim, Germany). The Bradford method was used to determine the protein concentration [47]. Cell lysates containing $30 \mu \mathrm{g}$ protein were separated by SDS-PAGE (15\% acrylamide), transferred to a Hybond $^{\mathrm{TM}}$ nylon membrane (GE Healthcare) and incubated for $1 \mathrm{~h}$ at room temperature in Blocking Solution. Membranes were incubated overnight at $4{ }^{\circ} \mathrm{C}$ with ph-insulin receptor, $\mathrm{ph}$-insulin substrate1, ph-insulin substrate2, ph-Akt, and ph-PI3K antibodies diluted (1:1500) with PBS. Then, membranes were washed for 30-60 min and incubated at room temperature for $1 \mathrm{~h}$ with the HRP-conjugated secondary antibody (New England Biolabs) diluted (1:1500) in PBS [48]. According to the manufacturer's instructions, immunoreactive proteins were detected using an enhanced chemiluminescence kit (GE Healthcare, Little Chalfont, UK) by a luminescent image analyzer (LAS-4000, Fujifilm Co., Tokyo, Japan). An antibody against $\beta$-actin (New England Biolabs, Hertfordshire, England) (1:1000) was used to detect $\beta$-actin, which was used as a loading control. Electrophoresis and electroblotting, using a discontinuous buffer system, were carried out in a Bio-Rad Trans-Blot SD Cell apparatus (Bio-Rad, Hercules, CA, USA). Densitometric analysis was then performed by using The Image Processing and Analysis Java (ImageJ, 1.8.0_172) program. Data were normalized to $\beta$-actin levels.

\subsection{Effect of Carpachromene on Hepatic Enzymes}

To examine the effect of carpachromene on PEPCK and HK hepatic enzymes activity, HepG2/IRM cells were seeded into a 6-well plate at a density of $3 \times 10^{5}$ cells per well. Cells were treated with $20 \mu \mathrm{g} / \mathrm{mL}$ carpachromene for $24 \mathrm{~h}$. Metformin was used as a positive control. Then, cells were washed three times with PBS. PEPCK assay kit (\#ab239714, Abcam, Waltham, MA, USA) and Hexokinase activity assay kit (\#ab136957, Abcam, Waltham, MA, USA) were utilized according to the manufacturer's instructions. A standard curve was obtained, and the absorbance was measured at $570 \mathrm{~nm}$ and $450 \mathrm{~nm}$ for PEPCK and HK, respectively, using an ELISA plate reader. The activities of PEPCK and HK were calculated from the standard curves. The experiments were performed in triplicates. 


\subsection{Statistical Analysis}

At least three independent experiments were used to obtain the results. Data were expressed as mean \pm standard deviation. One or two-way analysis of variance (ANOVA) followed by post hoc Dunnett test were used to analyse the differences of multiple comparison using GraphPad Prism 9 statistical software (GraphPad) and Excel software (Microsoft, Redwood, WA, USA). Differences were considered significant when the probability values $(\mathrm{P})$ were less than 0.05 .

\section{Conclusions}

This study examined, for the first time, the potential antidiabetic activity of carpachromene on a biochemical and molecular level. Our findings revealed that carpachromene showed central molecular regulation of glucose metabolism and insulin signalling via IR/IRS1/ PI3K/Akt/GSK3/FoxO1 pathway.

Supplementary Materials: The following are available online, Figure S1: ${ }^{1} \mathrm{H}$ NMR spectrum of Carpachromene, Figure S2: ${ }^{13} \mathrm{C}$ NMR spectrum of Carpachromene, Table S1: ${ }^{1} \mathrm{H}-\mathrm{NMR}$ spectral data of Carpachromene $\left(\mathrm{CD}_{3} \mathrm{OD}, 600 \mathrm{MHz}\right)$, Table S2: ${ }^{13} \mathrm{C}-\mathrm{NMR}$ spectral data of Carpachromene $\left(\mathrm{CD}_{3} \mathrm{OD}\right.$, $150 \mathrm{MHz})$.

Author Contributions: Conceptualization, R.A., Q.-L.Z. and M.F.; methodology, R.A. and H.A.H.; software, A.E.A.; validation, R.A., N.Y. and I.A.M.A.-R.; formal analysis, N.Y.; investigation, I.A.M.A.R. and M.F.; resources, S.F.A.; data curation, M.F. and Q.-L.Z.; writing—original draft preparation, R.A. and I.A.M.A.-R.; writing—review and editing, S.F.A., A.E.A., Q.-L.Z. and M.F.; visualization, H.A.H.; supervision, Q.-L.Z. and M.F.; project administration, A.E.A.; funding acquisition, S.F.A. and Q.-L.Z. All authors have read and agreed to the published version of the manuscript.

Funding: This work was supported by JSPS KAKENHI Grant Number (JP21K07614).

Institutional Review Board Statement: Not applicable.

Informed Consent Statement: Not applicable.

Data Availability Statement: All data are fully available and included in the manuscript.

Acknowledgments: Taif University Researchers Supporting Project Number (TURSP-2020/51), Taif, University, Taif, Saudi Arabia.

Conflicts of Interest: The authors declare no conflict of interest.

Sample Availability: Samples of the compound are not available from the authors.

\section{References}

1. James, D.E.; Stöckli, J.; Birnbaum, M.J. The aetiology and molecular landscape of insulin resistance. Nat. Rev. Mol. Cell Biol. 2021, 22, 751-771. [CrossRef]

2. Abdel-Hamid, N.; Fathy, M.; Amgad, S.W. Glycoregulatory Enzymes as Early Diagnostic Markers during Premalignant Stage in Hepatocellular Carcinoma. Am. J. Cancer Prev. 2013, 1, 14-19. [CrossRef]

3. Hammarstedt, A.; Gogg, S.; Hedjazifar, S.; Nerstedt, A.; Smith, U. Impaired adipogenesis and dysfunctional adipose tissue in human hypertrophic obesity. Physiol. Rev. 2018, 98, 1911-1941. [CrossRef]

4. Boucher, J.; Kleinridders, A.; Kahn, C. Insulin receptor signaling in normal and insulin-resistant states. Cold Spring Harb. Perspect. Biol. 2014, 6, a009191. [CrossRef]

5. Dong, X.C.; Copps, K.D.; Guo, S.; Li, Y.; Kollipara, R.; DePinho, R.A.; White, M.F. Inactivation of hepatic Foxo1 by insulin signaling is required for adaptive nutrient homeostasis and endocrine growth regulation. Cell Metab. 2008, 8, 65-76. [CrossRef] [PubMed]

6. Fathy, M.; Awale, S.; Nikaido, T. Phosphorylated Akt Protein at Ser473 Enables HeLa Cells to Tolerate Nutrient-Deprived Conditions. Asian Pac. J. Cancer Prev. 2017, 18, 3255-3260. [CrossRef] [PubMed]

7. Melvin, A.; O'Rahilly, S.; Savage, D. Genetic syndromes of severe insulin resistance. Curr. Opin. Genet. Dev. 2018, 50, 60-67. [CrossRef] [PubMed]

8. Teng, W.; Yin, W.; Zhao, L.; Ma, C.; Huang, J.; Ren, F. Resveratrol metabolites ameliorate insulin resistance in HepG2 hepatocytes by modulating IRS-1/AMPK. RSC Adv. 2018, 8, 36034-36042. [CrossRef] 
9. Axelsson, A.S.; Tubbs, E.; Mecham, B.; Chacko, S.; Nenonen, H.A.; Tang, Y.; Fahey, J.W.; Derry, J.M.; Wollheim, C.B.; Wierup, N. Sulforaphane reduces hepatic glucose production and improves glucose control in patients with type 2 diabetes. Sci. Transl. Med. 2017, 9. [CrossRef] [PubMed]

10. Hassan, H.A.; Allam, A.E.; Abu-Baih, D.H.; Mohamed, M.F.A.; Abdelmohsen, U.R.; Shimizu, K.; Desoukey, S.Y.; Hayallah, A.M.; Elrehany, M.A.; Mohamed, K.M.; et al. Isolation and characterization of novel acetylcholinesterase inhibitors from Ficus benghalensis L. leaves. RSC Adv. 2020, 10, 36920-36929. [CrossRef]

11. Tajuddeen, N.; Van Heerden, F.R. Antiplasmodial natural products: An update. Malar. J. 2019, 18, 404. [CrossRef]

12. Song, Y.; Wang, J.; Zhang, C.; Yu, Y.; Cai, H. Proapoptotic Protein Smac Mediates Apoptosis in Ovarian Cancer Cells When Treated with the Carpachromene. Arch. Med. Sci. 2021. [CrossRef]

13. Chen, L.W.; Cheng, M.J.; Peng, C.F.; Chen, I.S. Secondary metabolites and antimycobacterial activities from the roots of Ficus nervosa. Chem. Biodivers. 2010, 7, 1814-1821. [CrossRef]

14. Zheng, Z.P.; Cheng, K.W.; To, J.T.; Li, H.; Wang, M. Isolation of tyrosinase inhibitors from Artocarpus heterophyllus and use of its extract as antibrowning agent. Mol. Nutr. Food Res. 2008, 52, 1530-1538. [CrossRef] [PubMed]

15. Alaaeldin, R.; Abuo-Rahma, G.E.A.; Zhao, Q.L.; Fathy, M. Modulation of Apoptosis and Epithelial-Mesenchymal Transition E-cadherin/TGF-beta/Snail/TWIST Pathways by a New Ciprofloxacin Chalcone in Breast Cancer Cells. Anticancer Res. 2021, 41, 2383-2395. [CrossRef]

16. Alaaeldin, R.; Mustafa, M.; Abuo-Rahma, G.E.A.; Fathy, M. In vitro inhibition and molecular docking of a new ciprofloxacin chalcone against SARS-CoV-2 main protease. Fundam. Clin. Pharmacol. 2021, 1-11. [CrossRef]

17. Alaaeldin, R.; Nazmy, M.H.; Abdel-Aziz, M.; Abuo-Rahma, G.E.A.; Fathy, M. Cell Cycle Arrest and Apoptotic Effect of 7-(4-(Nsubstituted carbamoylmethyl) piperazin-1-yl) Ciprofloxacin-derivative on HCT 116 and A549 Cancer Cells. Anticancer Res. 2020, 40, 2739-2749. [CrossRef]

18. Eisa, M.A.; Fathy, M.; Abuo-Rahma, G.; Abdel-Aziz, M.; Nazmy, M.H. Anti-Proliferative and Pro-Apoptotic Activities of Synthesized 3,4,5 Tri-Methoxy Ciprofloxacin Chalcone Hybrid, through p53 Up-Regulation in HepG2 and MCF7 Cell Lines. Asian Pac. J. Cancer Prev. 2021, 22, 3393-3404. [CrossRef]

19. Fathy, M.; Sun, S.; Zhao, Q.-L.; Abdel-Aziz, M.; Abuo-Rahma, G.E.-D.A.; Awale, S.; Nikaido, T. A New Ciprofloxacin-derivative Inhibits Proliferation and Suppresses the Migration Ability of HeLa Cells. Anticancer Res. 2020, 40, 5025-5033. [CrossRef]

20. Oba, J.; Okabe, M.; Yoshida, T.; Soko, C.; Fathy, M.; Amano, K.; Kobashi, D.; Wakasugi, M.; Okudera, H. Hyperdry human amniotic membrane application as a wound dressing for a full-thickness skin excision after a third-degree burn injury. Burn. Trauma 2020, 8, tkaa014. [CrossRef]

21. Okabe, M.; Yoshida, T.; Suzuki, M.; Goto, M.; Omori, M.; Taguchi, M.; Toda, A.; Suzuki, T.; Nakagawa, K.; Hiramoto, F.; et al. Hyperdry Human Amniotic Membrane (HD-AM) is Supporting Aciclovir Included Device of Poly-N-p-VinylbenzylD-Lactonamide (PVLA) Sphere for Treatment of HSV-1 Infected Rabbit Keratitis Model. J. Biotechnol. Biomater. $2017,7,251$. [CrossRef]

22. Fawzy, M.A.; Maher, S.A.; Bakkar, S.M.; El-Rehany, M.A.; Fathy, M. Pantoprazole Attenuates MAPK (ERK1/2, JNK, p38)-NFkappaB and Apoptosis Signaling Pathways after Renal Ischemia/Reperfusion Injury in Rats. Int. J. Mol. Sci. 2021, $22,10669$. [CrossRef]

23. Aminudin, N.I.; Ahmad, F.; Taher, M.; Zulkifli, R.M. alpha-Glucosidase and 15-Lipoxygenase Inhibitory Activities of Phytochemicals from Calophyllum symingtonianum. Nat. Prod. Commun. 2015, 10, 1585-1587.

24. Dewi, K.; Widyarto, B.; Erawijantari, P.P.; Widowati, W. In vitro study of Myristica fragrans seed (Nutmeg) ethanolic extract and quercetin compound as anti-inflammatory agent. Int. J. Res. Med. Sci. 2015, 3, 2303-2310. [CrossRef]

25. Molinaro, A.; Becattini, B.; Mazzoli, A.; Bleve, A.; Radici, L.; Maxvall, I.; Sopasakis, V.R.; Molinaro, A.; Bäckhed, F.; Solinas, G. Insulin-driven PI3K-AKT signaling in the hepatocyte is mediated by redundant PI3K $\alpha$ and PI3K $\beta$ activities and is promoted by RAS. Cell Metab. 2019, 29, 1400-1409.e1405. [CrossRef] [PubMed]

26. Czech, M.P. Insulin action and resistance in obesity and type 2 diabetes. Nat. Med. 2017, 23, 804-814. [CrossRef]

27. Huang, Q.; Chen, L.; Teng, H.; Song, H.; Wu, X.; Xu, M. Phenolic compounds ameliorate the glucose uptake in HepG2 cells' insulin resistance via activating AMPK: Anti-diabetic effect of phenolic compounds in HepG2 cells. J. Funct. Foods 2015, 19, 487-494. [CrossRef]

28. Sagbo, I.J.; van de Venter, M.; Koekemoer, T.; Bradley, G. In vitro antidiabetic activity and mechanism of action of Brachylaena elliptica (Thunb.) DC. Evid.-Based Complement. Altern. Med. 2018, 2018, 4170372. [CrossRef]

29. Sefried, S.; Häring, H.-U.; Weigert, C.; Eckstein, S.S. Suitability of hepatocyte cell lines HepG2, AML12 and THLE-2 for investigation of insulin signalling and hepatokine gene expression. R. Soc. Open Biol. 2018, 8, 180147. [CrossRef] [PubMed]

30. Liu, X.; Li, L.; Li, J.; Cheng, Y.; Chen, J.; Shen, M.; Zhang, S.; Wei, H. Insulin resistance contributes to multidrug resistance in HepG2 cells via activation of the PERK signaling pathway and upregulation of Bcl-2 and P-gp. Oncol. Rep. 2016, 35, 3018-3024. [CrossRef]

31. Fathy, M.; Fawzy, M.A.; Hintzsche, H.; Nikaido, T.; Dandekar, T.; Othman, E.M. Eugenol exerts apoptotic effect and modulates the sensitivity of HeLa cells to cisplatin and radiation. Molecules 2019, 24, 3979. [CrossRef] [PubMed]

32. Naseem, M.; Othman, E.M.; Fathy, M.; Iqbal, J.; Howari, F.M.; AlRemeithi, F.A.; Kodandaraman, G.; Stopper, H.; Bencurova, E.; Vlachakis, D.; et al. Integrated structural and functional analysis of the protective effects of kinetin against oxidative stress in mammalian cellular systems. Sci. Rep. 2020, 10, 13330. [CrossRef] 
33. Fathy, M.; Khalifa, E.; Fawzy, M.A. Modulation of inducible nitric oxide synthase pathway by eugenol and telmisartan in carbon tetrachloride-induced liver injury in rats. Life Sci. 2019, 216, 207-214. [CrossRef] [PubMed]

34. Fathy, M.; Nikaido, T. In vivo modulation of iNOS pathway in hepatocellular carcinoma by Nigella sativa. Environ. Health Prev. Med. 2013, 18, 377-385. [CrossRef] [PubMed]

35. Abdellatef, A.A.; Fathy, M.; Mohammed, A.E.I.; Bakr, M.S.A.; Ahmed, A.H.; Abbass, H.S.; El-Desoky, A.H.; Morita, H.; Nikaido, T.; Hayakawa, Y. Inhibition of cell-intrinsic NF-kappaB activity and metastatic abilities of breast cancer by aloe-emodin and emodic-acid isolated from Asphodelus microcarpus. J. Nat. Med. 2021, 75, 840-853. [CrossRef] [PubMed]

36. Fathy, M.; Okabe, M.; Othman, E.M.; Saad Eldien, H.M.; Yoshida, T. Preconditioning of Adipose-Derived Mesenchymal Stem-Like Cells with Eugenol Potentiates Their Migration and Proliferation In Vitro and Therapeutic Abilities in Rat Hepatic Fibrosis. Molecules 2020, 25, 2020. [CrossRef]

37. Fathy, M.; Okabe, M.; Saad Eldien, H.M.; Yoshida, T. AT-MSCs Antifibrotic Activity is Improved by Eugenol through Modulation of TGF-beta/Smad Signaling Pathway in Rats. Molecules 2020, 25, 348. [CrossRef] [PubMed]

38. Fathy, M.; Nikaido, T. In vivo attenuation of angiogenesis in hepatocellular carcinoma by Nigella sativa. Turk. J. Med. Sci. 2018, 48, 178-186. [CrossRef] [PubMed]

39. Othman, E.M.; Fathy, M.; Bekhit, A.A.; Abdel-Razik, A.H.; Jamal, A.; Nazzal, Y.; Shams, S.; Dandekar, T.; Naseem, M. Modulatory and Toxicological Perspectives on the Effects of the Small Molecule Kinetin. Molecules 2021, 26, 670. [CrossRef]

40. Bian, G.; Yang, J.; Elango, J.; Wu, W.; Bao, B.; Bao, C. Natural Triterpenoids Isolated from Akebia trifoliata Stem Explants Exert a Hypoglycemic Effect via $\alpha$-Glucosidase Inhibition and Glucose Uptake Stimulation in Insulin-Resistant HepG2 Cells. Chem. Biodivers. 2021, 18, e2001030. [CrossRef]

41. Yang, Z.; Huang, W.; Zhang, J.; Xie, M.; Wang, X. Baicalein improves glucose metabolism in insulin resistant HepG2 cells. Eur. J. Pharmacol. 2019, 854, 187-193. [CrossRef] [PubMed]

42. Li, J.; Ding, X.; Jian, T.; Lü, H.; Zhao, L.; Li, J.; Liu, Y.; Ren, B.; Chen, J. Four sesquiterpene glycosides from loquat (Eriobotrya japonica) leaf ameliorates palmitic acid-induced insulin resistance and lipid accumulation in HepG2 Cells via AMPK signaling pathway. PeerJ 2020, 8, e10413. [CrossRef] [PubMed]

43. Sheu, Y.W.; Chiang, L.C.; Chen, I.S.; Chen, Y.C.; Tsai, I.L. Cytotoxic flavonoids and new chromenes from Ficus formosana f. formosana. Planta Med. 2005, 71, 1165-1167. [CrossRef]

44. Huang, X.; Liu, G.; Guo, J.; Su, Z. The PI3K/AKT pathway in obesity and type 2 diabetes. Int. J. Biol. Sci. 2018, 14, 1483. [CrossRef]

45. Li, X.; Monks, B.; Ge, Q.; Birnbaum, M.J. Akt/PKB regulates hepatic metabolism by directly inhibiting PGC-1 $\alpha$ transcription coactivator. Nature 2007, 447, 1012-1016. [CrossRef] [PubMed]

46. Goel, A.; Prasad, A.K.; Parmar, V.S.; Ghosh, B.; Saini, N. Apoptogenic effect of 7,8-diacetoxy-4-methylcoumarin and 7,8-diacetoxy4-methylthiocoumarin in human lung adenocarcinoma cell line: Role of NF-kappaB, Akt, ROS and MAP kinase pathway. Chem. Biol. Interact. 2009, 179, 363-374. [CrossRef] [PubMed]

47. Bradford, M.M. A rapid and sensitive method for the quantitation of microgram quantities of protein utilizing the principle of protein-dye binding. Anal. Biochem. 1976, 72, 248-254. [CrossRef]

48. Greenfield, E.A. Antibodies: A Laboratory Manual; Cold Spring Harbor Laboratory Press: Cold Spring Harbor, NY, USA, 2013. 